\title{
ISLAMIST NEWSPEAK \\ The Use of Arabic Terms as a Form of Cultural Hegemony in Political Communication by Muslim Fundamentalist Groups in Indonesia
}

\author{
Lestari Nurhajati | London School of Public Relations, Jakarta \\ Adam J. Fenton | London School of Public Relations, Jakarta \\ Corresponding author: lestari.n@lspr.edu
}

\begin{abstract}
Within Indonesian contemporary political discourse, fundamentalist groups are implementing a linguistic manipulation of Arabic terminology in order to influence the thinking of wider public. Prolific use of Arabic terminology in religious and political discourse is employed by such groups to baffle the thinking of impressionable audience. This study examines the use of Arabic terms by two Islamist groups in Indonesia, namely the Islamic Defenders Front (Front Pembela Islam/FPI) and Hizbut Tahrir Indonesia (HTI). It uses indepth interviews with leaders of those organizations combined with a critical discourse analysis approach. It examines the use of three key Arabic terms- 'jihad' 'khilafah' and 'habib'-to illustrate how the meaning of those words has been distorted compared with their generally accepted Indonesian definitions. The paper theorizes that this practice conforms to Gramscian notions of cultural hegemony, that a ruling elite manufactures the consent, loyalty and discipline of a mass of followers to uncritically conform to the preferred thought of the hegemony.
\end{abstract}

Keywords: Arabic terminology, political communication, cultural hegemony, fundamentalist groups.

\section{Introduction}

While estimates of the number of participants in Jakarta's 'Aksi Bela Islam 212 '(Action to Defend Islam 212) vary (from less than one million to 7.5 million), "what most people can agree on is that it was and still is the single largest street-level mass mobilization Indonesia 
has ever seen". ${ }^{1}$ While the action brought together a coalition of disparate Islamic groups, it was spearheaded by conservative Islamists such as the Islamic Defenders Front (Front Pembela Islam or 'FPI') who were demanding the imprisonment of the Jakarta Governor Basuki Tjahaya Purnama (popularly known as 'Ahok'), on charges of blasphemy. The movement which achieved the goal of imprisoning Ahok is demonstrative of a "kebangkitan Islam" (Islamic reawakening) which is gaining mass support, not only from groups which were previously considered to be fringe such as FPI (previously known for their 'sweeping 'operations, and attacks against Ahmadiyah minorities which earned them the epithet of 'gangsters in robes' but also mainstream Islamic organisations and leaders. ${ }^{2}$ Anies Baswedan the gubernatorial candidate supported by the action, later went on to win the election and became Governor of Jakarta. Baswedan appeared on stage at the one-year "reunion" of the 212 action in December, 2017.

The paper seeks to explore one avenue by which former fringe groups such as FPI have been able to gain influence in mainstream politics, and the widespread support of the public. Forming political alliances with powerful leaders is clearly one tactic. ${ }^{3}$ Another tactic is through the strategic use of Arabic phraseology and linguistic manipulation of the meanings of Arabic terms. It seeks to answer the following question: how do Islamist groups in Indonesia, particularly the FPI and Hizbut Tahrir Indonesia (HTI), interpret and use Arabic terminology, for their own interests, to gain political influence.

This paper begins by discussing the links between language and hegemonic political power, with particular reference to Indonesia. It then particularly examines the use of Arabic terms by two Islamist groups in Indonesia, namely the FPI and HTI. It employs in-depth interviews with leaders of those organisations combined with direct observations in the field, and uses a critical discourse analysis

\footnotetext{
1 "Reflections on a Reunion in Jakarta - New Mandala," accessed May 11, 2019, https://www.newmandala.org/reflections-reunion/.

2 “A Kinder, More Gentle FPI? - Inside Indonesia," accessed May 11, 2020, https://www.insideindonesia.org/a-kinder-more-gentle-fpi.

${ }^{3}$ Liam Gammon, "Is Populism a Threat to Indonesian Democracy?," in Democracy in Indonesia: Stagnation in Regression?, ed. Thomas Power and Eve Warburton (Singapore: ISEAS Publishing, 2020), 101.
} 
approach. It examines the use of three key Arabic terms— 'jihad' 'babib' and 'khilafah' - to illustrate how the meanings of those words have been distorted compared with the generally accepted Indonesian definitions to eliminate nuance and to influence thought so as to fall in line with the groups' interpretations and ideology.

This study uses a qualitative approach with a critical-constructivist paradigm; with critical discourse analysis (CDA) method as conceptualised by Norman Fairclough. Fairclough developed a threedimensional method for analysing discourse which focusses on; text, discourse practice, and social practice. In this paper the texts analysed are three Arabic words: jihad, kbilafah, and habib. ${ }^{4}$ The reason for choosing these words is because the usage of the words is becoming more frequent, both in everyday communication, either through the media or other channels. In discourse practice we interviewed key figures from FPI and HTI. The reason for choosing these two groups is based on their success in developing the organizations and gaining extensive media exposure from a number of mass media outlets.

Fairclough's CDA has three dimensions of data analysis, namely: text, text's production (discourse practice) and social context (sociocultural practice). The data used in this research based on these dimensions are: (1) Text: The definition of 'Jihad', 'Khilafah' and 'Habib' in the KBBI - Indonesia's most authoritative dictionary; (2) Discourse practice: the meaning of the texts and the productions of the texts by the institutions, based on in-depth interview results from key figures in the FPI and HTI; (3) Socio-cultural practice: The social context of those words in society (news reports for example). ${ }^{5}$

\section{Indonesia and Language}

Indonesia has more than 700 local languages. However, Bahasa Malayu, the lingua franca of trade in the region was chosen as the unifying national language, and became Bahasa Indonesia. The

\footnotetext{
${ }^{4}$ Norman Fairclough, Critical Discourse Analysis, The Critical Study of Language (New York: Longman Group Limited, 1995).

${ }^{5}$ Ibid..
} 
language has clear influences from a number of foreign sources including Portuguese, Dutch, English and Arabic among others. ${ }^{6}$

Change and evolution in the meaning of words is common in every language and society; especially in a large and culturally diverse country such as Indonesia. Arabic language has long been used in Indonesia as a language of instruction in religious schools (pesantren). Arabic script has also been used for writing the Malay language (Jawn). It is not unusual therefore that some Arabic terminology has entered the Indonesian lexicon.

However, this paper argues that there has been a shift in the use of Arabic language by particular groups, such as the FPI and HTI. Leading figures in such groups are using Arabic language more prolifically and fluently. The profuse usage of Arabic in speech, is intended to indicate that the user is 'more Islamic' which equates with greater moral purity and piety. This process attempts to conflate 'Arabic' with 'Islamic', to reinforce religious dogma which may not be challenged or reinterpreted, and to apply Islamic teachings to regulate Indonesian society, nation and state. People who are more fluent in Arabic, are immediately assumed to have religious superiority by their target audiences of ordinary Indonesians.

Jurgen Habermas in Communication and the Evolution of Society, ${ }^{7}$ posits that communication processes within a society will affect the evolution of the society itself. Javanese feudalis ${ }^{8}$ was reinforced by the linguistic structure. The highly structured Javanese language has several different levels, depending on the relative social status of the speaker and the listener. This differentiation of levels reinforces the segregation of class in Javanese culture through language. Bahasa Malayu was specifically chosen by Indonesia's founding fathers because of its egalitarian nature. Anderson speaks of Indonesian as a language of "attack" against Dutch colonialism and that it had a "democratic feel...which aspired to egalitarian norms...nationalism was then still partly seen in

\footnotetext{
${ }^{6}$ Karl Anderbeck, "Portraits of Language Vitality in the Languages of Indonesia," in Language Documentation and Cultural Practices in the Austronesian World, ed. I Wayan Arka (Canberra: Asia-Pacific Linguistics, 2015), 19-47.

${ }^{7}$ Jurgen Habermas, The Theory of Communicative Action, Reason and Rationalization of Society (Boston: Beacon Press Book, 1984).

${ }^{8}$ Bennedict Anderson, Language and Power: Exploring Political Cultures in Indonesia (Ithaca: Cornell University Press, 1990).
} 
terms of breaking out of 'Javanism' and the hierarchical modes of Javanese social intercourse". 9 As a cultural group, Javanese make up the majority of the population of Indonesia.

Attempts to further embed Arabic terminology in Indonesian society will therefore contribute to a transformative process that conflates Arabic language with Islam; which embeds Islamic tenets into mainstream thinking and leaves little room for alternative interpretations or debate.

Commenting on the deliberate use of esoteric and incomprehensible language in the indoctrination of young students in Indonesia's pesantren to 'manifest [the] power' of the spiritual leader, or kyai, Anderson wrote:

"The prestige of the kyai, rested on many factors, on his reputed ancestry, his powers, his experience, and his personal characterbut above all on his mastery of an esoteric vocabulary. The most important element in this vocabulary was, generally speaking, Arabic.

The normal method of instruction of boys and youths in the pesantren was the inculcation, by rote, of extensive passages of the Koran...Arabic was maintained as the language of "initiation" precisely because Arabic was not understood; the whole point of a spiritual ritual in an uncomprehended language is that it manifests power, and implies a deliberately nonrationalist mode of cognition". ${ }^{10}$

A teaching style which applies 'a deliberately non-rationalist mode of cognition' is clearly not one which encourages independent, critical thought. The goal would seem to be in fact, the opposite- to switch off thought, to promote blind acceptance of the lessons, interpretations and thinking of the hegemon. The paper argues that the leaders of Islamist groups, some of whom are themselves the products of the pesantren educational system, are attempting to apply this same strategy to both their members, and to the wider public.

Furthermore, the meaning behind Arabic terminology is increasingly pointed to by Islamist groups such as the FPI and HTI. This paper follows the classification of 'fundamentalist Islamic' groups

\footnotetext{
${ }^{9}$ Ibid., 139.

${ }^{10}$ Ibid., 127.
} 
set out by Mubarak. ${ }^{11}$ The term 'Islamist' is used to refer to groups and individuals that see the world primarily through the prism of Islamic teaching and seek to structure the state and society in accordance with Islamic principles. ${ }^{12}$ That is, that Islam is a complete ideology which must be applied in all aspects of civil and political life. That Islam ought to form the basis of the nation-state, and Islamic tenets ought to govern all aspects of social interactions. Islamic law should also form the basis of the legal system, including Islamic

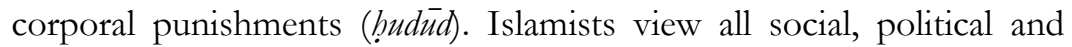
legal interactions through the prism of Islam and believe that Indonesia should be converted into an Islamic state. Some groups differ as to whether they consider it acceptable to use violence in the achievement of these goals. ${ }^{13}$

For the fundamentalist Islamic group, doctrine as found in the Qur'an and Hadith (Sunnah of Prophet Muhammad SAW) is a doctrine that is universal and has covered all aspects of human life. According to Mahendra, the doctrines as considered by fundamentalists are not limited by space and time, so they want to return to re-establish a society as they believe existed in the days of the Prophet and the Companions of the Prophet as an ideal age. ${ }^{14}$ The characteristics of fundamentalist Islam in applying the verses in the Qur'an and Hadith is based on a literal interpretation which is closed to any further discussion. ${ }^{15}$ Literalist Islamists read Qur'anic text in a literal way which does not take into account historical, technological, contextual changes, and metaphorical or symbolic significance of parables. "Closed" here means that the interpretation becomes the totality (kaffah) that cannot be further debated and is not open to other

\footnotetext{
${ }^{11}$ M. Zaki Mubarak, Genealogi Islam Radikal Di Indonesia, Gerakan, Pemikiran Dan Prospek Demokrasi (Jakarta: LP3ES, 2008).

12 "Local Jihad: Radical Islam and Terrorism in Indonesia | Australian Strategic Policy Institute | ASPI," accessed April 24, 2020, https://www.aspi.org.au/report/localjihad-radical-islam-and-terrorism-indonesia.

13 Masdar Hilmy, Islamism and Democracy in Indonesia: Piety and Pragmatism (Singapore: ISEAS Publishing, 2010).

14 Muhammad Wahyuni Nafis, Rekonstruksi Dan Renungan Religius Islam (Jakarta: Paramadina, 1996).

15 Abdurrahman Wahid, Ilusi Negara Islam, Ekspansi Gerakan Islam Transnasional Di Indonesia (Jakarta: The Wahid Institute, 2009).
} 
possibilities. Islamic fundamentalists do not understand the Qur'an as a collection of lessons learned (al-Furqān meaning 'lesson learned' is actually an alternative title for the Qur'an), but as a set of doctrines.

Islamist groups such as FPI and HTI, through the prolific use of Arabic terminology in their religious activities such as sermons and religious study groups, are making religious views inseparable from the political sphere; therefore, transforming Arabic terminology into a form of political communication. The use of digital communication technology by these groups amplifies and accelerates the use of Arabic as a vehicle of political communication. If this continues, the perception of Indonesia in world politics will be coloured by the terminology used by Islamic fundamentalists. Moreover, while Muslims form the vast majority of Indonesia's populace (about 229 million) ${ }^{16}$ the majority remain silent against the rising hegemony of Islamic fundamentalists.

\section{Language, Political Communication and Cultural Hegemony}

Chilton wrote in detail about the relationship of language and politics; the process of interaction, as well as representation, including the use of language with a religious approach that is used in political communication. ${ }^{17}$ According to Chilton, political tradition suggests that there is a close relationship between language and politics at a very fundamental level. ${ }^{18}$ Any form of human activity can therefore be interpreted as political activity, and this could not be possible without the use of language itself. That is to say that political action is the action of the language itself.

Meanwhile Nimmo posited that language in politics is a game with serious consequences; that those with finely honed rhetorical skills are those who gain power in democratic institutions. ${ }^{19}$ This phenomenon is reflected in the current situation whereby Islamist groups are gaining influence through the use Arabic language which is permeating into the general discourse of wider society.

\footnotetext{
16 Data taken from the World Population Review, https://worldpopulationreview.com/country-rankings/muslim-population-by-country.

17 Paul Chilton, Analysing Political Discourse: Theory and Practice (London and New York: Routledge, 2004).

18 Ibid., 16.

${ }^{19}$ Dan Nimmo, Komunikasi Politik (Bandung: Remaja Rosdakarya, 2005).
} 
The elimination of nuance, or shades of meaning, that are undesirable to the ruling party is reminiscent of Orwellian linguistic manipulation in the creation of a controlled language known as 'NewSpeak' in George Orwell's political portrayal of a dystopian, totalitarian future, in 1984. He wrote of NewSpeak that:

"Its vocabulary was so constructed as to give exact and often very subtle expression to every meaning that a Party member could properly wish to express, while excluding all other meaning and also the possibility of arriving at them by indirect methods. This was done partly by the invention of new words, but chiefly by eliminating undesirable words and stripping such words as remained of unorthodox meanings, and so far as possible of all secondary meaning whatever". ${ }^{20}$

Gramsci developed three main supporting ideas in his overall concept of hegemony. First: the hegemony of the culture and moral leadership. In this concept he saw civil society as being oppressed by the state as the holder of power in the form of police and military, combined with economic and monetary control. The second concept of hegemony, is that the state controls civil society through educational institutions. While the third concept of hegemony, is that civil groups can contribute to hegemony of civil society through their own activities.

According to Bocock, Gramsci sometimes defines the state as "political society" plus "civil society". So that the civil groups can also act as a hegemonizing force on other groups in society which are considered weaker. Gramsci's Prison Notebooks also make reference to the importance of language in the process of hegemony. ${ }^{21}$ Hegemonizing force may be exercised through influencing three core areas: 1 . The language itself, that is the totality of the various concepts and ideas predefined and not just words; 2. Concepts of common sense and policies (good sense); 3. popular religion, and the whole system of beliefs, superstitions, opinions, how to look at various things and how to act, collectively united under the name 'Folklore'. From understanding the above, it is clear that language on its own is just one

20 George Orwell, 1984 (New York: LeBook Publishing, 2020), 917.

21 Robert Bocock, Pengantar Komperhensif Untuk Memahami Hegemoni (Yogyakarta: Penerbit Jalasutra, 2007). 
means of exerting a hegemonic force on a society. Where one group is considered weak in its use of language and the other group is able to manipulate and control linguistic concepts, ideas and usage, this is where hegemony may occur.

\section{Manipulation of the Meaning of Terms: Jihäd, Khiläfah and Habib}

\section{Term of Jihäd}

\section{Text}

In the Indonesian context, based on Kamus Besar Bahasa Indonesia (KBBI - Indonesia's most authoritative dictionary), the word jihad is defined as follows:

"Jihäd n Isl 1. attempt by all means to achieve goodness; 2. earnest effort to defend Islam at the expense of property, soul, and body; 3. holy war against unbelievers to defend Islam; - great war; the fight against lust (evil); - Fi sabilillăh jihad in the path of Allah, (for the progress of Islam or to defend the truth); jiha $\bar{d}$ fought (in Allah's way); fight". ${ }^{22}$

\section{Discourse Practice}

As can be seen from this definition, there are at least three different meanings which can be attributed to the word. Representing FPI, in an interview, Secretary General Sobri Lubis ${ }^{23}$ accepted two different meanings of the word jiha $\bar{a}$. First, jih $\bar{a} d$ has the common sense meaning from the perspective of Arabic language derived from the word aj-jubd, meaning sincerity or earnestness. Whatever is done in earnest may therefore be characterised as jihäd. Secondly, jiha $\bar{a} d$ has a special meaning that is, to fight, for those who have been authorized by God to fight, in the cause of Allah against Islam's enemies, for example the heathen harbi (those hostile to Islam). This martial sense of jihad is also known as al-qităl jib $\bar{a} d \bar{f}$ Sabilillăh. Therefore, according to the FPI, as represented by its current leader, Sobri Lubis, it is not correct to refer to jihad only in the martial sense of participating in violent warfare. He said:

\section{2 https://kbbi.kemdikbud.go.id/entri/jihad}

${ }^{23}$ At the time of interview Sobri Lubis was the FPI Secretary General, however since 2017 is the leader of the organisation. 
"The two notions of jih $\bar{a} d$ should be taught to the public. The special meaning of jih $\bar{a}$, and the common meaning of jih $\bar{a}$, both are part of Islam, there is no separation. As the Prophet SAW said "Tholabul Halà Jihädun" "Making a living is jihäd". So making a living in a proper way is part of jihad. We cannot deny that. So to interpret jiha $\bar{d}$ only in the sense of war alone, is denying the Hadith of the prophet". ${ }^{24}$

While the dual meaning is acknowledged by the FPI, it is also the case that jiha $\bar{a}$ is often used as a justification for suicide attacks such as those which have occurred in Indonesia, notably Jakarta and Bali, on multiple occasions. ${ }^{25}$ Lubis responded by saying:

"It depends on the way you view the attacks. From a global perspective, attacks against the evil Americans, who are considered criminals by many Muslims, are part of jiba $\bar{a}$. However, if we look at local attacks in Indonesia, many of the victims are in fact Muslims, even though they may not have been the intended targets. In this case, jihäd causes victims for many different parties. And causes harm in particular to Muslims themselves". ${ }^{26}$

While it appears that the FPI reject the use of suicide bombings as a form of jib $\bar{a}$, an attitude of ambivalence becomes evident in comments such as this from Lubis:

"Yet we honour those who think, argue, globally. But from the FPI, we disagree. I have also held demonstrations, to reject bombings in the Republic of Indonesia in the name of jïăd. Like the bombing at the Marriott hotel, it is not right. But if it is done somewhere else, in the enemy's territory, not in Indonesia, it may be legitimate. But whatever they do, if they do it earnestly to destroy, to resist the infidel harbi, the USA, they will get their

\footnotetext{
${ }^{24}$ Interview with Sobri Lubis, 2009.

25 The terrorist attack in Bali on 12 October 2002 was the first case of a suicide terrorist attack in Indonesia, killing 202 people. Following that, suicide attacks have occurred in Jakarta on multiple occasions including, in 2006 (Australian Embassy), in 2003 (Marriott Hotel), in 2005 (Bali), in 2009 (Ritz-Carlton and Marriott hotels) and most recently in January 2016, (Sarinah, Central Jakarta). Each of these attacks were attributed to Jihadist terrorist groups including Jemaah Islamiyah and splinter groups.

${ }^{26}$ Interview with Sobri Lubis, 2009.
} 
reward, the reward of the mujähidin (fighters), because it depends on their intention". ${ }^{27}$

The statement shows that under certain circumstances, violent suicide attacks are accepted as a legitimate part of jihäd for the FPI leader, and hence members of the FPI organization. As Chusniyah has noted, the predominant understanding of most members of the FPI is that jihäd is a form of justified "sacred violence" that is, a form of violence which is legitimated by certain verses of Al-Qur'an. ${ }^{28}$

The interpretation of the term jih $\bar{a} d$ by HTI is far less ambiguous. According to HTI as expressed by their spokesperson Ismail Yusanto, jihăd is interpreted unequivocally as war, or qitāl. He said:

"Hizbut Tahrir understands jïhad as 'qital al-kuffar $\bar{f} \bar{i}$ sabilillah lillähi majidah'. That is, that jihäd means 'fighting the infidels'. Therefore qital is jibad" ${ }^{29}$

Yusanto was aware of alternative meanings of the term jihad but dismissed them. For HTI the meaning of jihad is equivalent with war, so the meaning of the word jihadd as earnest activity, working hard or studying hard, should not be accorded any importance. It is evident also in the official website of HTI that the explicit, true meaning of jibad is war and that other alternative meanings advanced by scholars should be rejected:

"Various methods are then applied; either nuanced or crude; using arguments which misinterpret the Qur'an and insult and distort the facts. These efforts attempt to change the meaning of jihad, among others by saying jib $\bar{a} d$ in Islam is defensive (to survive), not offensive. They also utilize scholars, purporting to be wise and pious to say, that the important thing is jibad against lust; this jih $\overline{a d}$ is jibäd akbar (great) compared to jibäd in the sense of war. There are also efforts to expand the meaning of jibäd to take on further meanings in language. There are also terms that were previously

\footnotetext{
${ }^{27}$ Interview with Sobri Lubis, 2009.

28 Muh. Amin Arqi Angga Yuni Mantara Tutut Chusniyah, "Menjadi Kelompok Minoritas Dalam Mayoritas; Persepsi Ancaman, Orientasi Dominasi Sosial, Dan Intoleransi Terhadap Jamaah Ahmadiyah," in International Conference on Islam and Civilizations (2019), 205-211.

${ }^{29}$ Interview with Ismail Yusanto, 2009.
} 
unknown in the time of Muhammad and the Salaf al-shälih, such as construction jibad, or political jihad, economic jihad, education jiba $\bar{a}$, and others. All this boils down to reducing the significance of the real sense of jiha $\bar{a}$, that of war". 30

\section{Sociocultural Practice}

It should be noted that the meaning of the term jihäd has long been debated, and no single sense of the word has been agreed upon. For example, the Arabic word jihäd jahada (abstract noun, jubd) means to try with all one's might, or all one's heart. ${ }^{31}$ In the early history of Muslims jihäd in the sense of a physical war, occurred when Muslims fought against the people of Mecca in the Badr Kubra event. ${ }^{32}$ When examined further, the physical jihäd of the Prophet and his companions during the events of Badr referred to jiba $\bar{d}$ in the sense of war but it was a defensive action in order to maintain the continuity of the Muslim community in Medina which at that time was still a limited, nascent community. The spirit of jibäd therefore aims not to undermine but rather to defend religious freedom. Although the FPI and HTI, recognise and apply different meanings of jibäd, they both assert that the word cannot be separated from the context of Islam, and its meaning is derived from the Qur'an and Hadith.

In the case of the 2016/7 movement to overthrow the formerGovernor of Jakarta, Basuki Tjahaha Purnama, alias Ahok, both FPI and HTI utilized the term jiba $\bar{d}$ in their calls for action at that time. Various media also repeated the use of the term in their reporting. One news outlet even quoted the FPI's East Sumatera chairperson, Habib Mahdi, who clearly used the word jibäd to oppose Ahok:

"The police do not fool the citizens. Ahok is insulting Islam. Beware the police about religious insults. Muslims are ready for jiba $\bar{d}$ in Jakarta. One word, we must fight Ahok. We love

\footnotetext{
${ }^{30}$ Hizbut Tahrir Indonesia, Manifesto Hižbut Tabrir Untuk Indonesia (Jakarta: Pustaka alIzzah, 2009).

31 M. Khadduri, Perang Dan Damai Dalam Islam (Yogyakarta: Tarawang Press, 2002).

32 Karen Amstrong, Berperang Demi Tuban (Bandung: Mizan, 1994).
} 
Indonesia, but if by Ahok's behaviour it has gone too far. Don't mess with Muslims." 33

The use of the term jihad in this context, reflects the FPI's preferred emphasis on the 'conflict or war' interpretation to the exclusion of the other broader meanings, as discussed above. The true broad meaning of the term has thus been significantly narrowed in this political discourse.

\section{Term of Khilafah}

\section{Text}

The word kbilafah is not found in the KBBI. However, khalifah is defined as follows:

Khalifah $n$ 1. The representative (successor) of the Prophet Muhammad after the Prophet's death (first in matters of state and religion) that implements Islamic law in national life; 2. (title) the religious head or king in Islamic countries; 3. ruler; manager of human beings created by God on the face of the earth. ${ }^{34}$

\section{Discourse Practice}

Whereas the word khalifab is included in the KBBI and aligns with the concept of caliph or religious ruler, the word kbilafah which aligns with the concept of a caliphate, a religious state which will be established and will lead the world towards the implementation of complete Islamic law, is not included in the KBBI. It is therefore not a concept which is recognised in the Indonesian lexicon. However, HTI has continued to disseminate and reinforce the concept of the khilafah as a central tenet of its ideological discourse, as well as the idea that when the Islamic khilafah arrives, all the problems experienced by Muslims around the world will be resolved. HTI has strenuously advocated the concept of the khilafah to Indonesian society, arguing that there are Qur'anic sources for it, however, a check of the Qur'an for the term khilafah reveals that it does not appear in the text.

33 "Aksi Serentak Dari DKI Hingga Daerah Kecam Ahok Soal Surah Al Maidah | Merdeka.Com," accessed April 24, 2020, https://www.merdeka.com/peristiwa/aksiserentak-dari-dki-hingga-daerah-kecam-ahok-soal-surah-al-maidah.html\#.

${ }^{34}$ https://kbbi.kemdikbud.go.id/entri/khalifah 
HTI, through the communications of its activists and cadres, explicitly advocates that the Indonesian government is now included in the category of kufr, and should be replaced by the Khilafah Islamizah. This is consistent with results of previous studies which emphasize the specific efforts of HTI to enforce the kbilafah Islamiyah. ${ }^{35}$ In various reports and books, HTI insists that the concept of khilafah Islamiyah cannot be separated from the meaning contained in the Qur'an and Hadith. It is also described in detail in the book Hizbut Tahrir Indonesia, ${ }^{36}$ which includes two verses of the Qur'an that are used to support the establishment of the khilafah; Al-Maidah (5): 48 and 49 which state:

"So judge between them by what Allah has revealed and do not follow their inclinations away from what has come to you of the truth. To each of you We prescribed a law and a method. Had Allah willed, He would have made you one nation [united in religion], but [He intended] to test you in what He has given you; so race to [all that is] good. To Allah is your return all together, and $\mathrm{He}$ will [then] inform you concerning that over which you used to differ". ${ }^{37}$

HTI claim that these verses support the idea of a mandatory establishment of a caliphate, however the word kbilafah or caliphate clearly does not appear there, and there are no further Qur'anic or Hadith instructions or explanation on the issue.

FPI's understanding and use of the term khilafah is different from HTI, however it appears to be moving closer to the HTI usage. Previously, FPI leadership espoused an understanding which aligned solely with Islamic leadership; the rule of the kbilafah, the leader, or Imamab-the concept that as in the days of the Prophet Muhammad and his Companions, the leadership should be held by one priest- the equivalent of a Pope-called the khilafah. As such, FPI formerly eschewed the establishment of a global caliphate. However, under the leadership of Habib Rizieq the position has moved to align more with

\footnotetext{
35 Mubarak, Genealogi Islam Radikal Di Indonesia, Gerakan, Pemikiran Dan Prospek Demokrasi.

36 Hizbut Tahrir Indonesia, Struktur Negara Khilafab: Pemerintab Dan Administrasi (Jakarta: HTI Press, 2005).

${ }^{37}$ Ibid.
} 
HTI and the mandatory establishment of a caliphate. With regard to the meaning of the word khilafah, FPI's then-Secretary General Sobri Lubis revealed:

"So when we refer to the kbilafah, as one who must be obeyed and he had a task so heavy so he was obeyed, then terms with the loss of the kbilafah, for example in Turkish, Ottoman Dawlah time was lost, then stop of regeneration, we no longer have a priest. Nowadays with the loss of the leadership, we were like orphans. No father who protects, no loving mother, we were all eaten by non-Muslim groups which resulted in the emergence of new expectations championed of hope is the reappearance of the kbilafah, the enforcement of the kbilafah. FPI agrees, it is part of the kbilafah religious duty. Just might stay context yes, what kind, not like say by Hizb, not like that, we are not in the context of it. So it is not the same in terms of technical thinking". 38

Although they have differing points of view, on the meaning of the khilafah, HTI and FPI have the same view, that it was an integral part of the Qur'an and Hadith.

\section{Sociocultural Practice}

The use of the term khilafah was used by HTI openly and vigorously in every demonstration where they opposed Ahok. As reported in a news report from the time, HTI in Mojokerto, East Java, also gave an anti Ahok speech with the theme of kbilafah:

"Dozens of Hizbut Tahrir Indonesia (HTI) activists in Mojokerto also held a demonstration at a number of points in Mojokerto City, East Java, on Friday, December 2, 2016. In addition to voicing demands for charges of blasphemy against the incumbent DKI Jakarta Governor, Basuki Tjahaja Purnama alias Ahok, HTI raised the issue of kbilafah or leadership according to Islamic law, which HTI has been dreaming of. HTI activists gave speeches in

38 "FPI Tolak Tuduhan Dirikan Negara Khilafah, Ahmad Sobri Lubis Angkat Bicara Jelaskan Soal Khilafah", Tribunnews.com, 4 December 2019. Retrieved from: https://www.tribunnews.com/nasional/2019/12/04/fpi-tolak-tuduhan-dirikan-negara-khilafah-ahmad-sobri-lubis-angkat-bicara-jelaskan-soal-khilafah. 
four locations ... They also held banners reading "Sharia and the Khilafah: Maintaining the Glory of Islam and National Unity". 39

The example is indicative HTI's efforts to insert a distorted concept of khilafah into the public discourse. In line with their political goals, the anti-Ahok demonstrations were a prime opportunity to push this agenda, that is the concept of an Indonesian Islamic state or khiläfah Islämiyah.

\section{Term of Habib}

\section{Text}

The KBBI defines the word habib as follows:

Habib $n$ 1. a loved one; lover; 2. The call to the Arabs, which means lord; a call to the person who holds Sayyid. ${ }^{40}$

\section{Discourse Practice}

For the FPI, habib is a term reserved for the descendants of the prophet Muhammad, and differs markedly from the general dictionary definition given above. It indicates very special status for those that claim it, especially within certain religious communities. According to current leader of FPI, Sobri Lubis:

"The descendants of the prophet in Indonesia are known as Habib; in other places they are known as 'Sayyid', or 'Syarif. For this they are special. Why like this, because it is associated with Islam, which is associated with them. They have special rights set out in this religion, so as to keep them from extinction. By maintaining this tradition, we ensure the effectiveness of Islamic law". ${ }^{41}$

Further, according to Lubis, the term Habib is part of Islamic law (sharia). As a descendant of the Prophet Muhammad special privileges are set forth in the Qur'an and Sunnah:

\footnotetext{
39 "Ikut Demo 212, Hizbut Tahrir Mojokerto Usung Isu Khilafah - Nasional Tempo.Co," accessed April 24, 2020, https://nasional.tempo.co/read/824989/ikutdemo-212-hizbut-tahrir-mojokerto-usung-isu-khilafah.

40 https://kbbi.kemdikbud.go.id/entri/habib.

${ }^{41}$ Interview with Sobri Lubis, 2009.
} 
"For example, in war, they are entitled to a greater share of the spoils of war. As the family of the Prophet, they are entitled to $25 \% " .42$

Attitudes and statements of various members of the FPI board indicate that the usage of titles such as Habib within the group are of great significance. When asked whether then-leader Habib Rizieq had taken offense when his name was mentioned in a variety of media without using the title 'ḅabib', Sobri insisted:

"I never saw Habib Rizieq offended, because the media didn't use the title 'Habib' but the students definitely did get offended, yes. For example, if the president was referred to with just his first name, how would we feel? Or for myself, as a cleric or 'Ustad' if I am not referred to as 'Ustad' probably my students would be offended if someone just referred to me as Sobri. My teachers taught me to always use such titles appropriately". ${ }^{3}$

So strong is the cult-like dependence of FPI members on the concept of the title 'Habib' as a descendant of the prophet, that much of the leader's influence is derived from its usage. This was especially evident in the case of Habib Rizieq. Rosadi showed that the identity of the group was strongly linked to the identity of Habib Rizieq, ${ }^{44}$ as if the life or death of FPI was dependent on the presence of Habib Rizieq.

Meanwhile HTI see the meaning of the word 'Habib' merely as a symbolic title or term which refers only to religious scholars and has no connection with claimed ancestry from the Prophet. When asked whether the significance of the title should be promoted or increased further, HTI spokesman Ismail Yusanto replied:

"No, this is not necessary, because the term does not exist in the Prophet's guidance (Sunnah); it does not state that the title Habib should be used. Sorry to say. It should be clarified if it is part of the culture or Islamic law, Syar'i'" ${ }^{45}$

\footnotetext{
42 Ibid.

43 Ibid.

${ }^{44}$ Rosadi Andriani, Hitam Putih FPI: Mengungkap Rahasia-Rabasia Mencengangkan Ormas Keagamaan Paling Kontroversial (Jakarta: Nun Publisher, 2008).

45 Ismail Yusanto, Interview, 2009.
} 
According to HTI, the usage of the term habib is therefore cultural, rather than based on religious scripture. So, an important distinction emerges in the usage of the term by these two groups, which is that for FPI "babib" derives from the Qur'an, whereas for HTI the usage of the term is merely linguistic.

\section{Sociocultural Context}

FPI's interpretation of the term habib led to significant public debate about the true meaning of the term in Indonesian media. One example is a Kumparan news report from early 2017, titled: "Those Who Deserve to be called Habib". The media interviewed Habib Ahmad Muhammad, an expert genealogist of the descendants of the prophet Muhammad in Indonesia. In his response he stressed that not everyone has the right to hold the title Habib. Although he did not directly discuss Habib Rizieq, he stated emphatically that someone with the title of Habib is subject to extra moral burdens and duties than regular people: "If someone with title of Habib commits a crime, we will usually go, question, then help him. If you do damage, it's very dangerous. The scholars say that his sins can multiply". ${ }^{46}$

In January 2017, Tirto.id news portal published a story titled "Many Habibs That Don't Reflect Good Morals". While the article questions whether there is a family relationship between the interviewee Quraish Shihab and FPI leader Habib Rizieq, Quraish Shihab when questioned about the term Habib, replied "Habib is a person who loves and is loved. So "love" in Arabic means "muhib". The "beloved" are "mahbüb". "Habib"... therefore cannot just want to be loved but not love others, it must be two-way". ${ }^{47}$ This interpretation recognizes that the usage of the term Habib is not dependent on genealogy, rather an attitude of love to others. Such an interpretation is contrary to the exclusive construction preferred by FPI.

The media reports quoted above show a clear tendency to interpret Arabic terminology such as habib in ways that are advantageous to the

\footnotetext{
46 "Mereka Yang Layak Disebut Habib - Kumparan.Com," accessed April 24, 2020, https://kumparan.com/kumparannews/mereka-yang-layak-disebut-habib.

47 “'Banyak Habib Yang Tidak Mencerminkan Akhlak Yang Baik' - Tirto.ID," accessed April 24, 2020, https://tirto.id/banyak-habib-yang-tidak-mencerminkan-akhlak-yangbaik-chxg.
} 
personal and political interests of the groups and individuals in question.

Table. Summary of Results of Analysis of Arabic Terms By FPI and HTI

\section{Level Analysis Result Analysis}

Text Based on in-depth interviews, each group has very different interpretations of the Arabic terms jiba d, kbiläah and habīib. Both groups claim textual rather than contextual meanings of each of the terms, derived from the Qur'an and Hadith. Different contradictory meanings and interpretations are not allowed.

Discourse Practice

\section{Sociocultural} Practice
HTI and FPI have produced their own meaning of each of the terms (jihäd, kbilafah and habīb) to promote their own varying versions of Islam and employ the terminology to support their goals. The general public as the consumers of the text are encouraged to accept the definitions offered by the two organisations.

Although in the wider community the terms jihäd, kbilafah and habib, have other meanings, as seen in the literature, these two groups (FPI and HTI), still interpret them according to the interests of their group. Then, this discourse is disseminated to the general public through propaganda, lectures, studies, and so on within the framework of their interpretation of Islam.

\section{Conclusion}

Differences in interpretation of the Arabic terms by these religious groups, reflect the interests of each group, to establish the meaning and form a collective meaning related to their interests. Although grammatically it cannot be denied that some Arabic terms has long been a part of the Indonesian words, the spread of new Arabic terminology over approximately the last two decades has been more intense.

The term jihäd is interpreted very differently by FPI and HTI. FPI interpret it more broadly, however HTI emphasize jiha $\bar{d}$ as physical war. Meanwhile, although the term khilafah is not found in the Qur'an or Hadith, HTI confirmed that this term is part of the heritage of the Qur'an and Hadith, because the kbilafab is a fundamental part of HTI's 
objectives, namely establishing Khiläah Islamiyah. Instead, the FPI does not consider the establishment of khilafah as part of the Qur'an and Hadith, since the establishment of the khilafah is not part of the purpose of the FPI. At the time of the research, the FPI did not support the idea of khilafah, however that position may be changing. The term Habib is crucial to the FPI group and plays a central role in the identity of it and its leader. It is believed to derive from the heritage of the Qur'an and Hadith, because Habib are the literal descendants of the Prophet. But for the HTI the term Habib is not part of the heritage of the Qur'an, but rather Arabic tradition.

While their interpretations of particular terms may be different, both groups utilise Arabic terminology in their own way with a similar ideological end in mind, that is, that Islam is the only solution for all of humanity's ills (al-Islam buwa al-hall). There remains a common thread which links the prolific usage of Arabic terminology by these groups which is a narrative that Arabic is the language of Islam, and that its mastery indicates superior knowledge and piety which creates greater power in the hands of the users of the language to influence the thinking of the wider community.[]

\section{References}

Amstrong, Karen. Berperang Demi Tuhan. Bandung: Mizan, 1994.

Anderbeck, Karl. "Portraits of Language Vitality in the Languages of Indonesia." In Language Documentation and Cultural Practices in the Austronesian World, edited by I Wayan Arka, 19-47. Canberra: Asia-Pacific Linguistics, 2015.

Anderson, Bennedict. Language and Power: Exploring Political Cultures in Indonesia. Ithaca: Cornell University Press, 1990.

Andriani, Rosadi. Hitam Putih FPI: Mengungkap Rahasia-Rahasia Mencengangkean Ormas Keagamaan Paling Kontroversial. Jakarta: Nun Publisher, 2008.

Bocock, Robert. Pengantar Komperhensif Untuk Memahami Hegemoni. Yogyakarta: Penerbit Jalasutra, 2007.

Chilton, Paul. Analysing Political Discourse: Theory and Practice. London and New York: Routledge, 2004.

Fairclough, Norman. Critical Discourse Analysis, The Critical Study of 
Language. New York: Longman Group Limited, 1995.

Gammon, Liam. "Is Populism a Threat to Indonesian Democracy?” In Democracy in Indonesia: Stagnation in Regression?, edited by Thomas Power and Eve Warburton. Singapore: ISEAS Publishing, 2020.

Habermas, Jurgen. The Theory of Communicative Action, Reason and Rationalization of Society. Boston: Beacon Press Book, 1984.

Hilmy, Masdar. Islamism and Democracy in Indonesia: Piety and Pragmatism. Singapore: ISEAS Publishing, 2010.

Hizbut Tahrir Indonesia. Manifesto Hiz̨but Tahrir Untuk Indonesia. Jakarta: Pustaka al-Izzah, 2009.

https://kbbi.kemdikbud.go.id/entri/jihad https://kbbi.kemdikbud.go.id/entri/khalifah https://kbbi.kemdikbud.go.id/entri/habib.

Hizbut Tahrir Indonesia. Struktur Negara Khilafab: Pemerintah Dan Administrasi. Jakarta: HTI Press, 2005.

Khadduri, M. Perang Dan Damai Dalam Islam. Yogyakarta: Tarawang Press, 2002.

Mubarak, M. Zaki. Genealogi Islam Radikal Di Indonesia, Gerakan, Pemikiran Dan Prospek Demokrasi. Jakarta: LP3ES, 2008.

Nafis, Muhammad Wahyuni. Rekonstruksi Dan Renungan Religius Islam. Jakarta: Paramadina, 1996.

Nimmo, Dan. Komunikasi Politik. Bandung: Remaja Rosdakarya, 2005.

Orwell, George. 1984. New York: LeBook Publishing, 2020.

Tutut Chusniyah, Muh. Amin Arqi Angga Yuni Mantara. "Menjadi Kelompok Minoritas Dalam Mayoritas; Persepsi Ancaman, Orientasi Dominasi Sosial, Dan Intoleransi Terhadap Jamaah Ahmadiyah." In International Conference on Islam and Civilizations, 205-211, 2019.

Wahid, Abdurrahman. Ilusi Negara Islam, Ekspansi Gerakan Islam Transnasional Di Indonesia. Jakarta: The Wahid Institute, 2009.

"A Kinder, More Gentle FPI? - Inside Indonesia." Accessed May 11, 2020. https://www.insideindonesia.org/a-kinder-more-gentlefpi.

“Aksi Serentak Dari DKI Hingga Daerah Kecam Ahok Soal Surah Al 
Maidah.” Accessed April 24, 2020. https://www.merdeka.$\mathrm{com} /$ peristiwa/aksi-serentak-dari-dki-hingga-daerah-kecamahok-soal-surah-al-maidah.html\#.

“'Banyak Habib Yang Tidak Mencerminkan Akhlak Yang Baik' Tirto.ID." Accessed April 24, 2020. https://tirto.id/banyakhabib-yang-tidak-mencerminkan-akhlak-yang-baik-chxg.

"Ikut Demo 212, Hizbut Tahrir Mojokerto Usung Isu Khilafah Nasional Tempo.Co.” Accessed April 24, 2020. https://nasional.tempo.co/read/824989/ikut-demo-212-hizbut-tahrirmojokerto-usung-isu-khilafah.

"Local Jihad: Radical Islam and Terrorism in Indonesia | Australian Strategic Policy Institute | ASPI.” Accessed April 24, 2020. https://www.aspi.org.au/report/local-jihad-radical-islam-andterrorism-indonesia.

"Mereka Yang Layak Disebut Habib - Kumparan.Com." Accessed April 24, 2020. https://kumparan.com/kumparannews/merekayang-layak-disebut-habib.

"Reflections on a Reunion in Jakarta - New Mandala." Accessed May 11, 2019. https://www.newmandala.org/reflections-reunion/.

\section{Interviews}

Interview with Sobri Lubis, 2009.

Interview with Ismail Yusanto, 2009. 